\title{
Phosphorus and potassium balance in soil under crop rotation and fertilization
}

\author{
Balanço de fósforo e potássio no solo sob rotação de \\ culturas e adubações
}

\author{
Fábio Steiner ${ }^{1 *}$; Laércio Augusto Pivetta ${ }^{1}$; Gustavo Castoldi ${ }^{1}$; \\ Mônica Sarolli Silva de Mendonça Costa ${ }^{2}$; Luiz Antonio de Mendonça Costa ${ }^{2}$
}

\begin{abstract}
The use of crop rotation and manure application can provide sustainability for an agricultural production system by improving soil quality and increasing nutrient use efficiency. This study aimed to evaluate the effect of mineral, organic and mineral+organic fertilization on grain yield and on soil phosphorus and potassium balance, in two crop systems under no-till, with and without rotation of cover crops. The experiment was carried out from 2006 to 2008 on a clayey Rhodic Hapludox in Marechal Cândido Rondon, Paraná State, Brazil. The cropping sequence in the rotation system involving cover crops was black oat + hairy vetch + forage turnip/corn/pigeon pea/wheat/mucuna + brachiaria + sunn hemp, and in the succession system was wheat/corn/wheat/soybean. Organic and mineral+organic fertilizations consisted of the application of solely manure and manure combined with mineral fertilizer, respectively. Soil $\mathrm{P}$ and $\mathrm{K}$ balances were calculated after the second year of the experiment, up to a depth of $0.40 \mathrm{~m}$. First year corn yields were higher in the crop succession system accompanied by mineral fertilization. In the second year, wheat and soybean yield did not vary between crop systems and nutrient sources, demonstrating the residual effect of crop rotation and manure use. Crop rotation with cover crops resulted in an increase in soil $\mathrm{K}$ levels by promoting the recycling of this nutrient in the soil. In both crop systems, the application of mineral and organic fertilizers - either in isolation or in combination resulted in a negative soil $\mathrm{P}$ and $\mathrm{K}$ balance in the short term. This represents a threat to the sustainability of the agricultural production system in the long term, due to the depletion of soil nutrient reserves.
\end{abstract}

Key words: Organic fertilization, fertilizer, cover crops, soil nutrient, no-till

\section{Resumo}

A utilização de rotação de culturas e a aplicação de esterco pode conferir sustentabilidade ao sistema de produção agrícola, por melhorar a qualidade do solo e aumentar a eficiência de uso de nutrientes. O objetivo deste trabalho foi avaliar o efeito da adubação mineral, orgânica e mineral+orgânica na produtividade de grãos e no balanço de fósforo e de potássio no solo em dois sistemas de culturas sob plantio direto, com e sem rotação de plantas de cobertura. O experimento foi conduzido em Marechal Cândido Rondon, Paraná, Brasil, de 2006 a 2008, em um Latossolo Vermelho. A sequência de culturas no sistema em rotação com plantas de cobertura foi aveia preta + ervilhaca + nabo/milho/guandu/trigo/ mucuna + braquiária + crotalária / milho, e no sistema em sucessão foi trigo/milho/trigo/soja/milho. As adubações, orgânica e mineral+orgânica consistiram, respectivamente, da aplicação de esterco e

\footnotetext{
${ }^{1}$ Doutorando(s) em Agronomia/Agricultura. Dept ${ }^{\mathrm{o}}$ de Produção Vegetal. Faculdade de Ciências Agronômicas. Universidade Estadual Paulista Júlio de Mesquita Filho, FCA/UNESP. Fazenda Experimental Lageado, Botucatu, SP. E-mail: fsteiner@fca. unesp.br; laerciopivetta@fca.unesp.br; castoldi@fca.unesp.br

${ }^{2}$ Profs. da Universidade Estadual do Oeste do Paraná, UNIOESTE, Centro de Ciências Exatas e Tecnológicas, Cascavel, PR. E-mail: monica.costa@unioeste.br; lmendo@ig.com.br

*Author for corespondence
} 
de esterco combinado com fertilizante mineral. $\mathrm{O}$ balanço de $\mathrm{P}$ e de $\mathrm{K}$ no solo foi avaliado, após o segundo ano de condução do experimento, na camada de $0,0-0,40 \mathrm{~m}$ de profundidade. A produtividade do milho, no primeiro ano, foi superior na sucessão de culturas e na adubação mineral. No segundo ano, a produtividade de trigo e de soja não se alterou entre os sistemas de culturas e fontes de nutrientes, o que demonstra o efeito residual da rotação de culturas e do uso de esterco. Rotação de culturas com plantas de cobertura proporcionou aumento na quantidade de $\mathrm{K}$ no solo, por favorecer o processo de ciclagem deste nutriente do solo. Ambos os sistemas de culturas associados à aplicação fertilizante mineral e esterco de forma isolada ou combinada resultaram em saldo negativo do balanço de $\mathrm{P}$ e $\mathrm{K}$ no solo em curto prazo, representando uma ameaça para a sustentabilidade do sistema de produção em longo prazo, devido o esgotamento das reservas desses nutrientes do solo.

Palavras-chave: Adubação orgânica, fertilizante, plantas de cobertura, nutriente do solo, plantio direto

\section{Introduction}

The use of conservation cropping systems such as no-till has been presented as a viable alternative with which to promote the sustainability of soil fertility and thus also its agricultural exploitation. However, the success of the system depends, among other factors, on the input of large amounts of straw on the soil surface. There is evidence that no-till cash-crop cultivation can result in soil degradation (TAVARES FILHO; BARBOSA; RIBON, 2010) by favoring increased soil bulk density and penetration resistance, and reducing total porosity (TAVARES FILHO et al., 2001). On the other hand, important benefits have been observed in terms of soil structure and crop yield, in both the medium and long term, as a result of using cover crops with a high capacity to produce dry matter (COSTA et al., 2011; CALONEGO; ROSOLEM, 2008; CALEGARI et al., 2006).

The use of different crop rotation systems can improve nutrient use efficiency, increasing the production potential through the nutrient cycling process (BOER et al., 2007). Among the main characteristics to be considered in the choice of planted species as cover crops are dry matter production and capacity to recycle nutrients (OLIVEIRA; CARVALHO; MORAES, 2002). In general, grasses used as cover crops are efficient in extracting nutrients from the soil and in recycling in crop rotation systems. Among the many plant species that can be used as cover crops in no-till systems in the State of Paraná, black oat (Avena strigosa Schreb), forage turnip
(Raphanus sativus L.), brachiaria (Brachiaria sp.) and sunn hemp (Crotalaria sp.) are presented as excellent alternatives, both as monocrops and for intercropping (CALEGARI, 2006).

In addition to crop rotation, use of animal manure as fertilizer has been an important management strategy for the improvement of soil quality (MOSADDEGHI; MAHBOUBI; SAFADOUST, 2009; GOMES et al., 2005). Manure application provides an excellent nutrient source for plants and, when handled properly, can supply partially or completely the mineral fertilizer (GOMES et al., 2005; MATSI; LITHOURGIDIS; GAGIANAS, 2003), as well as reducing production costs. However, the use of the no-till system has brought major changes in the use of manure and management practices. Manure was previously applied onto the surface and immediately incorporated into the soil, but is currently applied onto the layer of straw necessary to the no-till system and left on the soil surface. This form of manure application prevents or retards contact between the fertilizer and the soil and microorganisms, with possible repercussions for the mineralization of organic compounds in the dynamics and balance of soil nutrients (SCHERER; NESI, 2009).

Nutrient balance in the soil has been increasingly used to evaluate the effects of fertilizer management and crop rotations in production systems. According to Hanáčková, Macák and Candráková (2008), calculations of soil nutrient balance in agricultural production systems provides some basic information for assessing their long-term sustainability. The 
difference between amount of nutrient exported with grains and applied as fertilizers indicates the level of increase or decrease in soil nutrient content; when the outputs of a particular nutrient are larger than the inputs in the farming system, the condition is one of unsustainability (OENEMA; KROS; DE VRIES, 2003). It is therefore important for the adequate management of phosphate and potassic fertilization to estimate the balance of these nutrients in the soil. This is because the insufficient application of fertilizer can lead to a negative balance, resulting in decreased soil fertility, which affects the yield and profitability of system resources and leads to soil degradation (SINGH; SINGH; REDDY, 2002). On the other hand, the excessive application of fertilizer leads to an excessively positive balance, resulting in low nutrient use efficiency and low economic performance (BALIGAR; FAGERIA, HE, 2001), with losses also intensified by erosion and leaching (ROSOLEM et al., 2010). Studies indicate that there is a negative nutrient balance (HANÁČKOVÁ; MACÁK; CANDRÁKOVÁ, 2011; 2008; ANDRIST-RANGEL et al., 2007; BHATTACHARYYA et al., 2006; DOBERMANN; CRUZ; CASSMAN, 1996), representing a threat to sustainability of the agricultural production system due to depletion of the soil nutrients reserves.

Studies that address soil nutrient balance in Brazil are still limited to the soils of Paraná State. However, this work is essential in order to evaluate the effects of different tillage systems and crop rotations comprising the no-till system in the State. Thus, the aim of this study was to determine the effect of mineral, organic and mineral+organic fertilization on grain yield, and on soil phosphorus and potassium balance in two crop systems under no-till, with and without rotation of cover crops.

\section{Material and Methods}

The experiment was carried out at the Agronomic Experimental Station, Universidade Estadual do
Oeste do Paraná (West Paraná State University) in Marechal Cândido Rondon Municipality, Paraná State, Brazil (latitude: $24^{\circ} 31^{\prime} \mathrm{S}$, longitude: $54^{\circ} 01^{\prime}$ W, altitude: $420 \mathrm{~m}$ ). The soil was a Rhodic Hapludox (Latossolo Vermelho eutroférrico under the Brazilian classification) with 630,260 and $110 \mathrm{~g} \mathrm{~kg}^{-1}$ of clay, silt and sand, respectively. The climate according to the Köppen classification is $\mathrm{Cfa}$, characterized as subtropical humid (mesothermal) with hot summers and a tendency towards high rainfall levels (average temperature above $22^{\circ} \mathrm{C}$ ), and winters with infrequent frosts (average temperature below $18^{\circ} \mathrm{C}$ ). The climate has no defined season, while average annual rainfall is around 1,500 $\mathrm{mm}$. Rainfall and temperature data gathered during the experiment are shown in Figure 1.

The experimental area had been under no-till for six years, cropped to soybean/wheat/soybean/ corn in rotation. Before starting the experiment, soil samples were collected at depths of $0.0-0.10$; $0.10-0.20$ and $0.20-0.40 \mathrm{~m}$. The results of chemical analysis are shown in Table 1.

The experimental was arranged in a randomized block design with treatments in a $2 \times 3$ factorial, with four replications. Treatments consisted of two crop systems: (i) succession: wheat/corn/wheat/ soybean and (ii) rotation: black oat + hairy vetch + forage turnip/corn/pigeon pea/wheat/mucuna + brachiaria + sunn hemp, combined with one of three different nutrient sources (mineral, organic and mineral+organic). The area of each plot was 7.4 $\times 12.0 \mathrm{~m}$ (total $\left.88.8 \mathrm{~m}^{2}\right)$.

Fertilization of crops for grain production (wheat, corn and soybeans) was performed according to the specific needs of each crop (RAIJ et al., 1997) and soil analysis. Mineral and manure fertilizers were applied both separately and in combination, thus resulting in the three different nutrient sources: mineral, organic and mineral+organic, respectively. The amount of manure as organic fertilizer was applied based on the primary needs of each culture, according to an analysis of the manure and the 
recommended culture guidelines. Mineral+organic fertilization was performed in the form of an initial application of manure, with the addition of mineral fertilizer supplementing levels of other nutrients as recommended. Cover crops did not receive fertilizer application.

Figure 1. Total monthly rainfall $(\mathrm{mm})$ and monthly average temperature $\left({ }^{\circ} \mathrm{C}\right)$ during the experiment. I-implementation of the experiment, $1^{\text {st }}$ and $2^{\text {nd }}$ - first and second soil sampling, respectively.

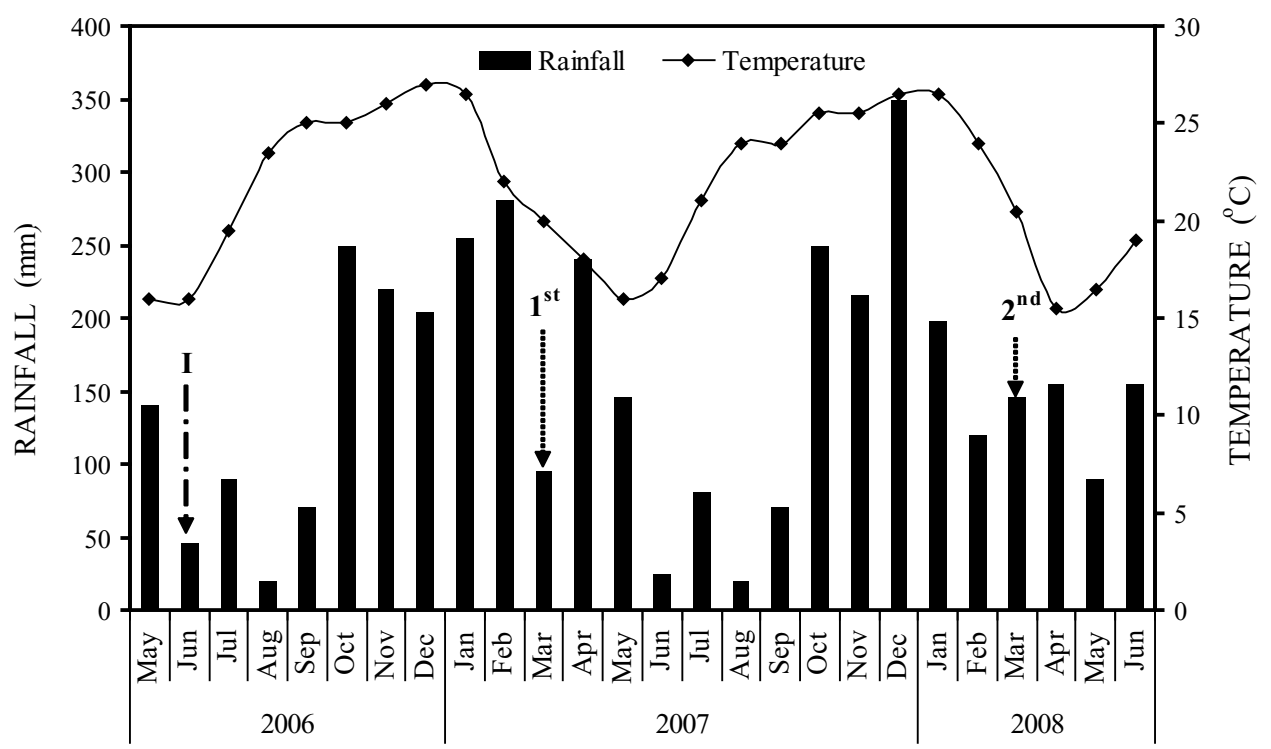

Source: Elaboration of the authors.

Table 1. Soil chemical properties and bulk density at $0.0-0.10,0.10-0.20$, and $0.20-0.40 \mathrm{~m}$ depth at the beginning of the experiment.

\begin{tabular}{|c|c|c|c|c|c|c|c|c|c|c|c|}
\hline Depth & $\mathrm{pH}_{\mathrm{CaCl} 2}$ & O.M. $^{a}$ & $\mathrm{P}_{\text {Mehlich-1 }}$ & $\mathrm{H}+\mathrm{Al}$ & $\mathrm{Ca}$ & $\mathrm{Mg}$ & $\mathrm{K}_{\mathrm{ex}}$ & $\mathrm{K}_{\text {non-ex }}{ }^{\mathrm{b}}$ & $\mathrm{CEC}^{\mathrm{c}}$ & $\mathrm{V}^{\mathrm{d}}$ & $\mathrm{Ds}^{\mathrm{e}}$ \\
\hline (m) & & $\mathrm{g} \mathrm{dm}^{-3}$ & $\mathrm{mg} \mathrm{dm}^{-3}$ & --- & ----- & $\mathrm{mmc}$ & $\mathrm{dm}^{-3}$ & & ---- & $\%$ & $\mathrm{~g} \mathrm{~cm}^{-3}$ \\
\hline $0.0-0.10$ & 4.8 & 28.2 & 16.8 & 62 & 30 & 15 & 3.6 & 7.0 & 110 & 44 & 1.31 \\
\hline $0.10-0.20$ & 4.7 & 25.3 & 6.8 & 65 & 27 & 15 & 2.5 & 7.1 & 110 & 41 & 1.35 \\
\hline $0.20-0.40$ & 4.6 & 18.9 & 2.7 & 68 & 23 & 13 & 1.3 & 7.7 & 105 & 35 & 1.30 \\
\hline
\end{tabular}

${ }^{a}$ O.M.: organic matter. ${ }^{\mathrm{b}} \mathrm{K}_{\text {non-ex }}$ : non-exchangeable $\mathrm{K}$, obtained as the difference in the amount of $\mathrm{K}_{\text {extracted by boiling } 1 \mathrm{~N} \text { HNO }}$ and that extracted via the Mehlich-1 method. ${ }^{\mathrm{c}} \mathrm{CEC}$ : cation exchange capacity. ${ }^{\mathrm{d}} \mathrm{V}$ : soil base saturation. ${ }^{\mathrm{e}}$ Ds: soil bulk density.

Source: Elaboration of the authors.

The two experimental crop systems were initially established in June 2006. The sowing of intercropping cover crops [black oat (Avena strigosa Schreb) + hairy vetch (Vicia villosa Roth) + forage turnip (Raphanus sativus L. var. oleiferus Metzg)] was performed via the addition of 50 ,
20 and $10 \mathrm{~kg} \mathrm{ha}^{-1}$ of the seeds of oats, vetch and turnip, respectively, in $0.17 \mathrm{~m}$ spaced rows, without the supply of any fertilizer. At 75 days after plant emergence (DAPE), the plants were desiccated with glyphosate $\left(0.80 \mathrm{~kg} \mathrm{ha}^{-1}\right.$ a.i. $)$ at a spray volume of $180 \mathrm{~L} \mathrm{ha}^{-1}$. Wheat (Triticum aestivum L., cv. IPR 
85) was sown in $0.17 \mathrm{~m}$-spaced rows at a density of 350 seeds $\mathrm{m}^{-2}$. Mineral fertilization was carried out by applying $200 \mathrm{~kg} \mathrm{ha}^{-1} 10-10-15$ formulation at sowing, and $50 \mathrm{~kg} \mathrm{ha} \mathrm{h}^{-1} \mathrm{~N}$ topdressing in the form of urea at the beginning of plant's tillering. Organic and mineral+organic fertilization was carried out by applying $25 \mathrm{~m}^{3} \mathrm{ha}^{-1}$ of pig slurry alone and supplemented with $5 \mathrm{~kg} \mathrm{ha} \mathrm{ha}_{2} \mathrm{P}_{5}$ (triple superphosphate - TSP) and $12 \mathrm{~kg} \mathrm{ha}^{-1} \mathrm{~K}_{2} \mathrm{O}$ (potassium chloride $-\mathrm{KCl}$ ), respectively. The pig slurry used had the following physical and chemical characteristics: $2.4 \%$ dry matter; $2.00 \mathrm{~g} \mathrm{dm}^{-3} \mathrm{~N}$; $0.60 \mathrm{~g} \mathrm{dm}^{-3} \mathrm{P}_{2} \mathrm{O}_{5}$ and $0.72 \mathrm{~g} \mathrm{dm}^{-3} \mathrm{~K}_{2} \mathrm{O}$.

Corn (Zea mays L., PIONEER 30F80 hybrid) was sown at a density of 5 seeds $\mathrm{m}^{-1}$ on 14 October 2006, on crop residues of winter crops in rows spaced $0.80 \mathrm{~m}$ apart. Mineral fertilization was carried out by applying $188 \mathrm{~kg} \mathrm{ha}^{-1}$ 08-28-16 formulation at sowing, and $105 \mathrm{~kg} \mathrm{ha}^{-1} \mathrm{~N}$ topdressing in the form of urea. Organic and mineral+organic fertilization was carried out by applying $38 \mathrm{~m}^{3} \mathrm{ha}^{-1}$ of pig slurry alone and supplemented with $2 \mathrm{~kg} \mathrm{ha}^{-1} \mathrm{P}_{2} \mathrm{O}_{5}$ (TSP) and $5 \mathrm{~kg} \mathrm{ha}^{-1} \mathrm{~K}_{2} \mathrm{O}(\mathrm{KCl})$, respectively. The pig slurry used had the following physical and chemical characteristics: $3.7 \%$ dry matter; $3.15 \mathrm{~g} \mathrm{dm}^{-3} \mathrm{~N}$; $1.37 \mathrm{~g} \mathrm{dm}^{-3} \mathrm{P}_{2} \mathrm{O}_{5}$ and $0.78 \mathrm{~g} \mathrm{dm}^{-3} \mathrm{~K}_{2} \mathrm{O}$.

In March 2007 after the corn was harvested, pigeon pea [Cajanus cajan (L.) DC.] was sown at a density of 20 seeds $\mathrm{m}^{-1}$ in the treatments involving rotation with cover crops in $0.45 \mathrm{~m}$-spaced rows, without the supply of fertilizers. At 35 days after plant emergence, the pigeon pea was desiccated with glyphosate $\left(0.7 \mathrm{~kg} \mathrm{ha}^{-1}\right.$ a.i. $)$ using a spray volume of $150 \mathrm{~L} \mathrm{ha}^{-1}$.

Wheat (Triticum aestivum L., cv. CD 208) was sown on 31 May 2007, in rows $0.17 \mathrm{~m}$ apart at a density of 400 seeds $\mathrm{m}^{-2}$. Mineral fertilization was carried out by applying $100 \mathrm{~kg} \mathrm{ha}^{-1} 10-10-30$ formulation at sowing, and $50 \mathrm{~kg} \mathrm{ha}^{-1} \mathrm{~N}$ topdressing at the beginning of plant's tillering in the form of urea. Organic and mineral+organic fertilization was carried out by applying $2.1 \mathrm{Mg} \mathrm{ha}^{-1}$ of poultry manure alone and supplemented with $9 \mathrm{~kg} \mathrm{ha}^{-1} \mathrm{~N}$ (urea) and $19 \mathrm{~kg} \mathrm{ha}^{-1} \mathrm{~K}_{2} \mathrm{O}(\mathrm{KCl})$, respectively. Acquired from a poultry farm, the physical and chemical characteristics of the poultry manure were as follows: $92 \%$ dry matter, $20.0 \mathrm{~g} \mathrm{~kg}^{-1} \mathrm{~N}, 4.85 \mathrm{~g}$ $\mathrm{kg}^{-1} \mathrm{P}_{2} \mathrm{O}_{5}$ and $5.40 \mathrm{~g} \mathrm{~kg}^{-1} \mathrm{~K}_{2} \mathrm{O}$.

After the wheat was harvested, either intercropping cover crops or soybeans were sown in their respective treatments. Intercropping cover crops [mucuna (Stizolobium niveum Kuntze) + brachiaria (Brachiaria ruziziensis Germain et Everard) + sunn hemp (Crotalaria juncea L.)] were sown in $0.45 \mathrm{~m}$-spaced rows at densities of 30,10 and $20 \mathrm{~kg}$ seeds ha ${ }^{-1}$ for mucuna, brachiaria and sunn hemp, respectively, without the addition of fertilizer. At 75 days after plant emergence, the plants were desiccated with glyphosate $(0.80 \mathrm{~kg}$ $\mathrm{ha}^{-1}$ a.i.) at a spray volume of $180 \mathrm{~L} \mathrm{ha}^{-1}$. Soybean [Glycine $\max$ L. (Merrill), cv. CD 204] was sown in $0.45 \mathrm{~m}$ spaced rows at a density of 18 seeds $\mathrm{m}^{-1}$. Mineral fertilization was carried out by applying $200 \mathrm{~kg} \mathrm{ha}^{-1}$ 00-30-20 formulation at sowing, while organic and mineral+organic fertilization involved applying $4.5 \mathrm{Mg} \mathrm{ha}^{-1}$ of cattle manure compost alone and supplemented with $51 \mathrm{~kg} \mathrm{ha}^{-1} \mathrm{P}_{2} \mathrm{O}_{5}$ (TSP), respectively. The cattle manure compost used had the following physical and chemical characteristics: $87 \%$ dry matter, $15.4 \mathrm{~g} \mathrm{~kg}^{-1} \mathrm{~N}, 2.0 \mathrm{~g} \mathrm{~kg}^{-1} \mathrm{P}_{2} \mathrm{O}_{5}$ and $8.9 \mathrm{~g} \mathrm{~kg}^{-1} \mathrm{~K}_{2} \mathrm{O}$.

In September 2006 and March 2008, the amount of straw produced by intercropping of cover crops (black oat + hairy vetch + forage turnip, and mucuna + brachiaria + sunn hemp) was estimated by taking samples from three random points per plot, using a $0.25 \mathrm{~m}^{2}$ wooden frame. The collected plant material was then dried in a forced-air oven for $72 \mathrm{~h}$ at $60 \pm$ $3^{\circ} \mathrm{C}$, weighed, ground, digested in nitric-perchloric acid and $\mathrm{P}$ was determined colorimetrically and $\mathrm{K}$ content were determined by atomic absorption spectrophotometry (MALAVOLTA; VITTI; OLIVEIRA, 1997). The total amount of $\mathrm{P}$ and $\mathrm{K}$ accumulated in cover crops was calculated by multiplying the nutrient contents by the mass of dry matter produced. 
In March 2007 and 2008, after the harvest and/ or management of summer crops, soil samples were collected down to a depth of $0.40 \mathrm{~m}$ using a hole auger in five different points per plot. These samples were air-dried, passed through a $2.0 \mathrm{~mm}$ sieve and levels of $\mathrm{P}$ and $\mathrm{K}$ determined via the Mehlich-1 method (EMBRAPA, 1997). Initially measured in $\mathrm{mg} \mathrm{dm}{ }^{-3}$, soil $\mathrm{P}$ and $\mathrm{K}$ concentrations were converted to $\mathrm{kg} \mathrm{ha}^{-1}$ by multiplying the calculated values by the volume of soil in a square hectare down to 0.40 $\mathrm{m}$ depth (i.e. $4 \times 10^{3} \mathrm{~m}^{3}$ ).

Soil $\mathrm{P}$ and $\mathrm{K}$ balance $\left(\mathrm{kg} \mathrm{ha}^{-1} \mathrm{yr}^{-1}\right)$ was calculated after the second year of the experiment as the sum of the total amount of each nutrient applied as fertilizer $\left(\mathrm{kg} \mathrm{ha}^{-1}\right)$, the change in the amount of $\mathrm{P}$ and $\mathrm{K}$ in a layer of soil to $0.40 \mathrm{~m}$ depth $\left(\mathrm{kg} \mathrm{ha}^{-1}\right)$ and the total amount exported in harvested grain $\left(\mathrm{kg} \mathrm{ha}^{-1}\right)$, all divided by the duration of the assessment period (years), according to the following equations:

Soil P balance $=\left[\mathrm{P}_{\text {Fertulzer }}+\left(\mathrm{P}_{\text {Inttal Soll }}-\mathrm{P}_{\text {Final Soll }}\right)-\right.$ $\mathrm{P}_{\text {EХтовтеD }}$ / assessment period

Soil K balance $=\left[\mathrm{K}_{\text {Fertulzer }}+\left(\mathrm{K}_{\text {Inttal Soll }}-\mathrm{K}_{\text {Final SolL }}\right)-\right.$ $\left.\mathrm{K}_{\text {EхровтеD }}\right]$ / assessment period

A negative value for the soil $\mathrm{P}$ and $\mathrm{K}$ balance was interpreted as a net release of organic $\mathrm{P}$ and nonexchangeable $\mathrm{K}$, whereas a positive value indicated that net fixation of $\mathrm{P}$ and $\mathrm{K}$ had taken place, respectively. The amount of $\mathrm{P}$ and $\mathrm{K}$ exported in the form of wheat (2007 and 2008), corn (2006/07) and soybean (2008/09) was estimated based on the average concentration of each nutrient in the above grains according to the Manual of Fertilizer Recommendation for the State of Sao Paulo (RAIJ et al., 1997) and the grain yield obtained. For each ton of wheat, corn and soybean grains produced, around $5 \mathrm{~kg} P$ and $5 \mathrm{~kg} \mathrm{~K} ; 4 \mathrm{~kg} P$ and $5 \mathrm{~kg} \mathrm{~K}$, and $6 \mathrm{~kg} \mathrm{P}$ and $19 \mathrm{~kg} \mathrm{~K}$, respectively, are removed from the soil.
The obtained results were first subjected to an ANOVA, with the means for each different crop system and fertilizer/nutrient source then compared via the $F$ test $(p<0.05)$ and Tukey test $(p<0.05)$, respectively, for each year of assessment.

\section{Results and Discussion}

\section{Dry matter production and grain yield}

The amount of dry matter produced by cover crops was $5,184 \pm 514 \mathrm{~kg} \mathrm{ha}^{-1}$ for intercropping black oat/hairy vetch/forage turnip, and 10,296 \pm $1,030 \mathrm{~kg} \mathrm{ha}^{-1}$ for intercropping mucuna/brachiaria/ sunn hemp. This high dry matter production of cover crops, especially for intercropped mucuna+brachiaria+sunn hemp, it becomes extremely important for improving soil quality in notill system, mainly by reduce soil bulk density and penetration resistance, increase total soil porosity (COSTA et al., 2011), and improve the structure of soil aggregates (CALONEGO; ROSOLEM, 2008; CALEGARI et al., 2006).

The amount of $\mathrm{P}$ and $\mathrm{K}$ accumulated in cover crops was $36 \pm 4$ and $96 \pm 11 \mathrm{~kg} \mathrm{ha}^{-1}$ for intercropping black oat/hairy vetch/forage turnip, and $41 \pm 5$ and $154 \pm 16 \mathrm{~kg} \mathrm{ha}^{-1}$ for intercropping mucuna/brachiaria/ sunn hemp, respectively. The high capacity of these plants to extract soil nutrients, especially $\mathrm{K}$, reflects the important role cover crops play in nutrient cycling in soils under crop rotation systems.

The highest corn grain yield was obtained in the crop succession system (Table 2), and can likely be attributed to a residual effect of wheat fertilization. In contrast, the lower corn yield observed in the crop rotation system is probably due to the fact that the intercropping of cover crops was not accompanied by the application of fertilizer. However, the wheat yield did not differ between the rotation and succession cropping systems (Table 2), demonstrating the cumulative effect of growing cover crops. 
Table 2. Grain yield of wheat, corn and soybean under different crop systems and nutrient sources.

\begin{tabular}{|c|c|c|c|c|c|}
\hline \multirow[b]{2}{*}{ Crop systems } & \multirow[b]{2}{*}{ Nutrient sources } & \multicolumn{4}{|c|}{ Crops (harvest) } \\
\hline & & $\begin{array}{l}\text { Wheat } \\
(2007)\end{array}$ & $\begin{array}{c}\text { Corn } \\
(2007 / 08)\end{array}$ & $\begin{array}{l}\text { Wheat } \\
(2008)\end{array}$ & $\begin{array}{c}\text { Soybean } \\
(2008 / 09)\end{array}$ \\
\hline & & \multicolumn{4}{|c|}{$\mathrm{kg} \mathrm{ha}^{-1}$} \\
\hline \multirow{4}{*}{ Succession $^{\dagger}$} & Mineral & $1,655 \mathrm{a}$ & $7,369 \mathrm{a}$ & $1,195 \mathrm{a}$ & $3,743 \mathrm{a}$ \\
\hline & Organic & $1,599 \mathrm{a}$ & $6,577 \mathrm{~b}$ & $1,062 \mathrm{a}$ & $3,661 \mathrm{a}$ \\
\hline & Mineral+organic & $1,684 \mathrm{a}$ & $6,515 \mathrm{~b}$ & $1,238 \mathrm{a}$ & $3,864 \mathrm{a}$ \\
\hline & Mean & 1,645 & $6,820 \mathrm{~A}$ & $1,165 \mathrm{~A}$ & 3,789 \\
\hline \multirow{4}{*}{ Rotation } & Mineral & - & $7,185 \mathrm{a}$ & $1,041 \mathrm{a}$ & - \\
\hline & Organic & - & $6,094 \mathrm{~b}$ & $1,008 \mathrm{a}$ & - \\
\hline & Mineral+organic & - & $5,260 \mathrm{~b}$ & $1,102 \mathrm{a}$ & - \\
\hline & Mean & - & $6,180 \mathrm{~B}$ & $1,050 \mathrm{~A}$ & - \\
\hline
\end{tabular}

${ }^{\dagger}$ Succession: wheat/corn/wheat/soybean. ${ }^{\star}$ Rotation: black oat + hairy vetch + forage turnip/corn/pigeon pea/wheat/mucuna + brachiaria + sunn hemp. Values represented by the same lower case letters, between the nutrients sources and same upper case letters, into of each crop systems are not different according to the Tukey test and F test, both at the 0.05 level of confidence.

Source: Elaboration of the authors.

The highest corn yield, obtained after the application of mineral fertilizer, is likely due to increased soil nutrient availability with respect to that resulting from the use of manure (organic and mineral+organic fertilization) (Table 2), which releases nutrients more slowly. In contrast, wheat (harvested 2006 and 2007) and soybean (harvested 2007/08) grain yield was not affected by nutrient source variation (Table 2), indicating that manure application - when used either alone or in combination with mineral fertilizer - completely met crop nutritional requirements. In their study of nutrient sources, Matsi, Lithourgidis and Gagianas (2003) found that the application of $40 \mathrm{~m}^{3} \mathrm{ha}^{-1}$ of liquid cattle manure increased wheat yield to levels equivalent to those produced after the addition of mineral fertilizer in the four years of assessment. Gomes et al. (2005) obtained similar corn yields when fertilizing with organic composted manure, either alone or in combination with mineral fertilizer, and mineral fertilizer alone.

\section{Soil phosphorus and potassium balance}

Crop system did not affect the total amount of available soil $\mathrm{P}$ in the first year of the experiment (Figure 2A). By the end of the second year however, the highest amounts of $\mathrm{P}$ were observed in soils under the crop succession system, with these increased $\mathrm{P}$ levels likely representing a residual effect of fertilization of the cash crops (Figure 2B). In contrast, cover crops were not fertilized in the rotation system, resulting in lower soil $\mathrm{P}$ content, at least in the short term. The latter low levels also probably reflect $\mathrm{P}$ absorbed by plants being retained in crop residues remaining on the soil surface. It should be noted that such retained $\mathrm{P}$ will be largely available for future plant uptake after the decomposition of plant residues. The $\mathrm{P}$ mineralization rate in plant residues left on the soil surface in of no-till systems has been found to be similar to the decomposition rate of organic matter (BOER et al., 2007). 
Figure 2. Soil phosphorus levels at $0.0-0.40 \mathrm{~m}$ depth in the first (A) and second year (B) of the experiment, under different crop systems and nutrient sources. Bars represented by the same lower case letters, for each crop system and same upper case letters, for each nutrient source are not different (Tukey, $\mathrm{p}<0.05$ ). Succession: wheat/corn/wheat/ soybean. Rotation: black oat + hairy vetch + forage turnip/corn/pigeon pea/wheat/mucuna + brachiaria + sunn hemp. Vertical bars represent standard deviation of the mean $(n=4)$.

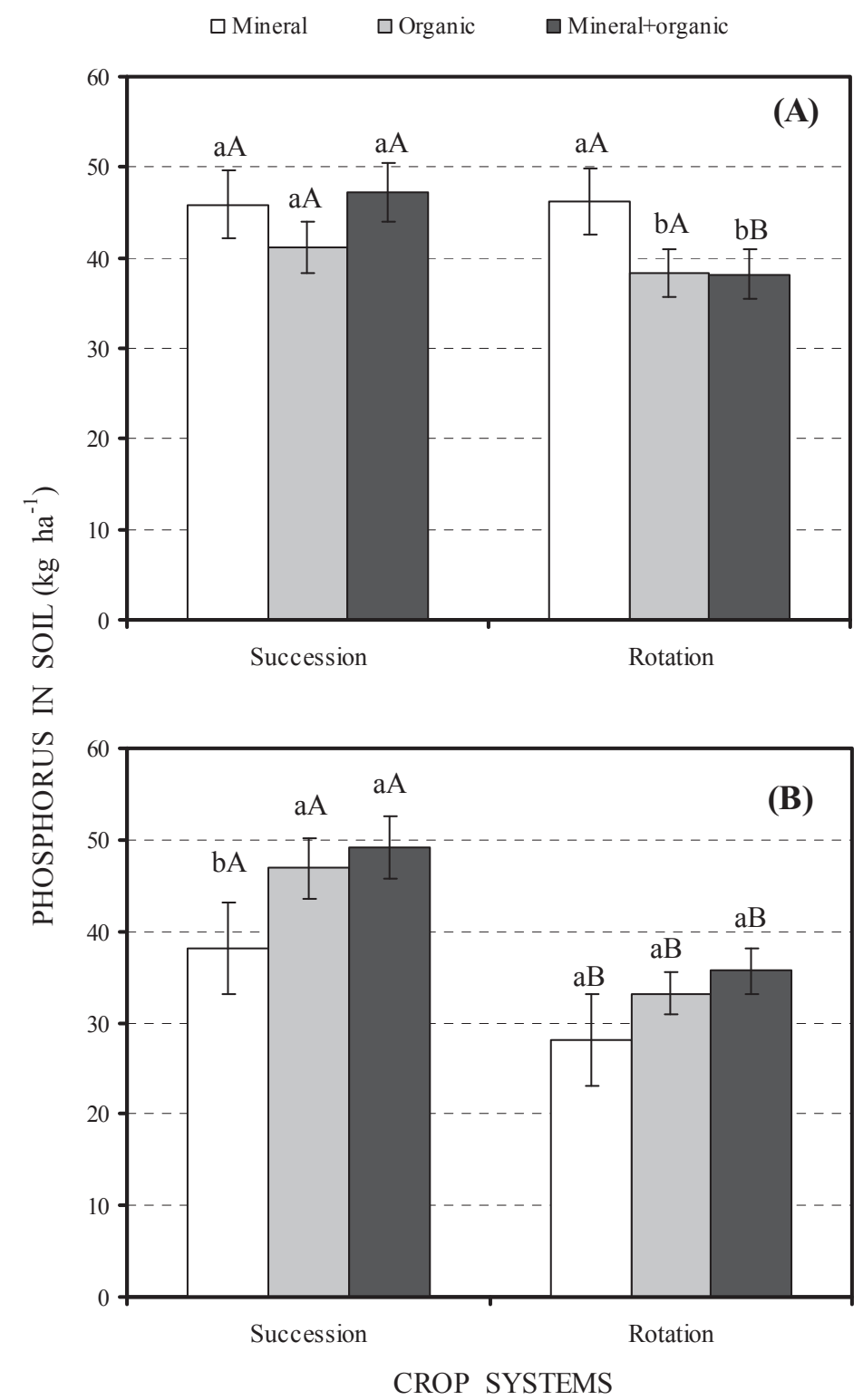

Source: Elaboration of the authors.

The amount of $\mathrm{P}$ in soil under crop rotation was higher in mineral fertilization as compared to organic or mineral+organic fertilization, while P levels under crop succession did not vary between any fertilizer type (Figure 2A). The lower soil P content, in the short term at least, of those soils undergoing manure (organic and mineral+organic fertilization) rather than mineral fertilizer application, can be attributed to the gradual release of $\mathrm{P}$ from the organic sources used in the former.

The absence of any nutrient source impact on the amount of soil $\mathrm{P}$ in the crop succession 
system (Figure 2A) is likely a residual effect of the fertilization of winter wheat grown previously. In the second year, the increase in $\mathrm{P}$ availability in the same system (Figure 2B) as a result of manure application (organic and mineral+organic fertilization) represents a combination of the residual effect and the gradual release of $\mathrm{P}$ from organic sources, leaving this nutrient less available for adsorption to the soil. According to Souza et al. (2006), organic fertilization reduces the adsorption/ precipitation of $\mathrm{P}$ in soil by increasing organic matter content, thus increasing $\mathrm{P}$ availability in the soil. On the other hand, if $\mathrm{P}$ is immediately released into the soil as occurs with the addition of mineral fertilizers, it is more likely to be adsorbed and its availability for crops reduced. In the crop rotation system, variation in nutrient source did not affect soil $\mathrm{P}$ availability (Figure $2 \mathrm{~B}$ ).

The highest soil $\mathrm{K}$ content observed after the first year of the experiment was found in the crop rotation system (Figure 3), with these values probably reflecting the capacity of cover crops to recycle this nutrient. Assessing nutrient cycling by cover crops in cerrado soil, Boer et al. (2007) found $\mathrm{K}$ to be the most accumulated, with levels reaching around $417 \mathrm{~kg} \mathrm{ha}^{-1}$ in pearl millet. In a study conducted in Botucatu, São Paulo State, Brazil, Garcia et al. (2008) were able to confirm that the introduction of brachiaria in the system resulted in larger amounts of straw being retained on the soil surface, as well as higher levels of $\mathrm{K}$ recycling. The same authors also observed that brachiaria plants extracted considerable amounts of non-exchangeable $\mathrm{K}$ from the soil, increasing levels of exchangeable $\mathrm{K}$ in the surface soil layer. Following cover-crop desiccation, the $\mathrm{K}$ extracted from the soil was then washed out of plant residues and returned to the soil in exchangeable form, ready to be available for the next crop. Potassium may be almost completely released from straw before tissue decomposition because it is present in plant organs as an ion and is not bound to organic compounds (MARSCHNER, 1995). After submitting residues of black oat, millet, sorghum, sun hemp, brachiaria and triticale to simulated rainfall, Rosolem, Calonego and Foloni (2003) observed considerable amounts of $\mathrm{K}$ to be present in the leachate, with values ranging from 7 to $24 \mathrm{~kg} \mathrm{ha}^{-1}$ for $8 \mathrm{Mg} \mathrm{ha}^{-1}$ of dry residue matter.

The low levels of soil K observed in organicallyfertilized treatments in both years of the experiment (Figure 3) is probably due to the lower amounts of this nutrient found in the applied manure. Crops fertilized only with this organic manure received no supplementary nutrients (to recommended levels), unlike those treatments under mineral+organic fertilization. In the crop rotation system, variation in nutrient source did not affect soil $\mathrm{K}$ availability in either year of the evaluation (Figure 3).

Soil $\mathrm{P}$ balance was negative for all treatments (Figure 4), indicating that organic forms of the element contribute a significant amount to overall plant $\mathrm{P}$ supply. This organic contribution has been frequently reported in the literature, even in situations involving phosphate fertilizer application (BECK; SANCHES, 1994; GATIBONI et al., 2005). In soils with low $\mathrm{P}$ content and little or no phosphate fertilization, organic forms of $\mathrm{P}$ act as the main sources of the nutrient for plants (GATIBONI et al., 2007). The largest soil $\mathrm{P}$ deficit was observed in the crop succession system, with values ranging from -7 to $-21 \mathrm{~kg} \mathrm{ha}^{-1} \mathrm{yr}^{-1} \mathrm{P}$ for mineral and organic fertilization, respectively (Figure 4). In soils under crop rotation, $\mathrm{P}$ balance values were lower at between -3 and $-4 \mathrm{~kg} \mathrm{ha}^{-1} \mathrm{yr}^{-1} \mathrm{P}$, independent of nutrient source (Figure 4). Evaluating the soil nutrient balance of five different crop rotation systems under conventional and minimum tillage, Hanáčková, Macák and Candráková (2008) found that the incorporation of cover crop residues into soil resulted in a positive balance of $4 \mathrm{~kg} \mathrm{ha}^{-1}$ year $^{-1} \mathrm{P}$ in both cropping systems. However, the permanence of the area during the fallow period growing season resulted in a deficit of $-24 \mathrm{~kg} \mathrm{ha}^{-1}$ $\mathrm{yr}^{-1} \mathrm{P}$. These data reflect the importance of crop rotation in many agricultural production systems because it represents a significant nutrient reserve. 
Figure 3. Soil potassium levels at $0.0-0.40 \mathrm{~m}$ depth in the first (A) and second year (B) of the experiment, under different crop systems and nutrient sources. Bars represented by the same lower case letters, for each crop system and same upper case letters, for each nutrient source are not different (Tukey, $\mathrm{p}<0.05$ ). Succession: wheat/corn/wheat/ soybean. Rotation: black oat + hairy vetch + forage turnip/corn/pigeon pea/wheat/mucuna + brachiaria + sunn hemp. Vertical bars represent standard deviation of the mean $(n=4)$. Vertical bars represent standard deviation of the mean $(\mathrm{n}=4)$.

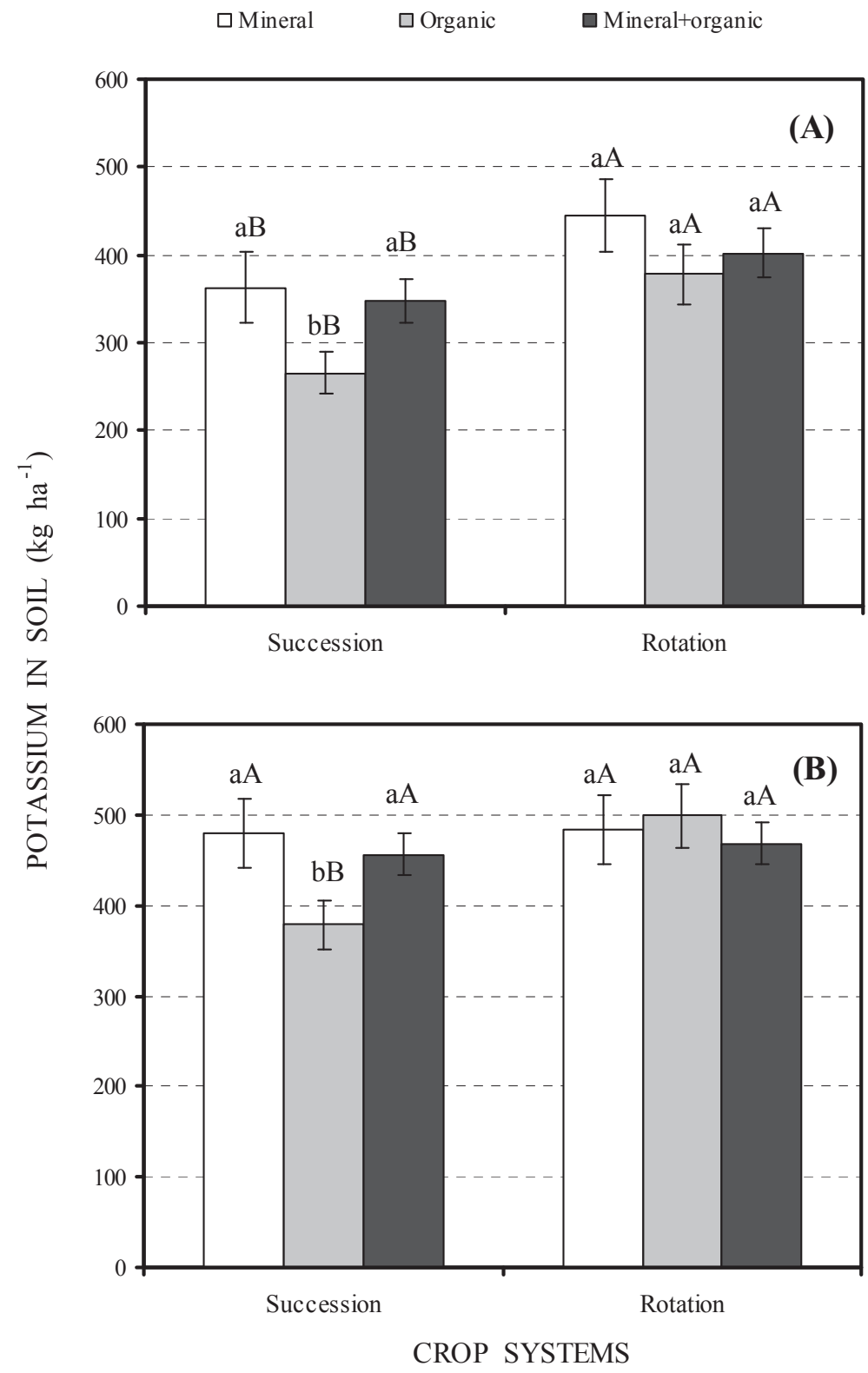

Source: Elaboration of the authors. 
Figure 4. Soil phosphorus and potassium balance up to $0.40 \mathrm{~m}$ depth under different crop systems and nutrient sources. Succession: wheat/corn/wheat/soybean. Rotation: black oat + hairy vetch + forage turnip/corn/pigeon pea/ wheat/mucuna + brachiaria + sunn hemp. Vertical bars represent standard deviation of the mean $(n=4)$.
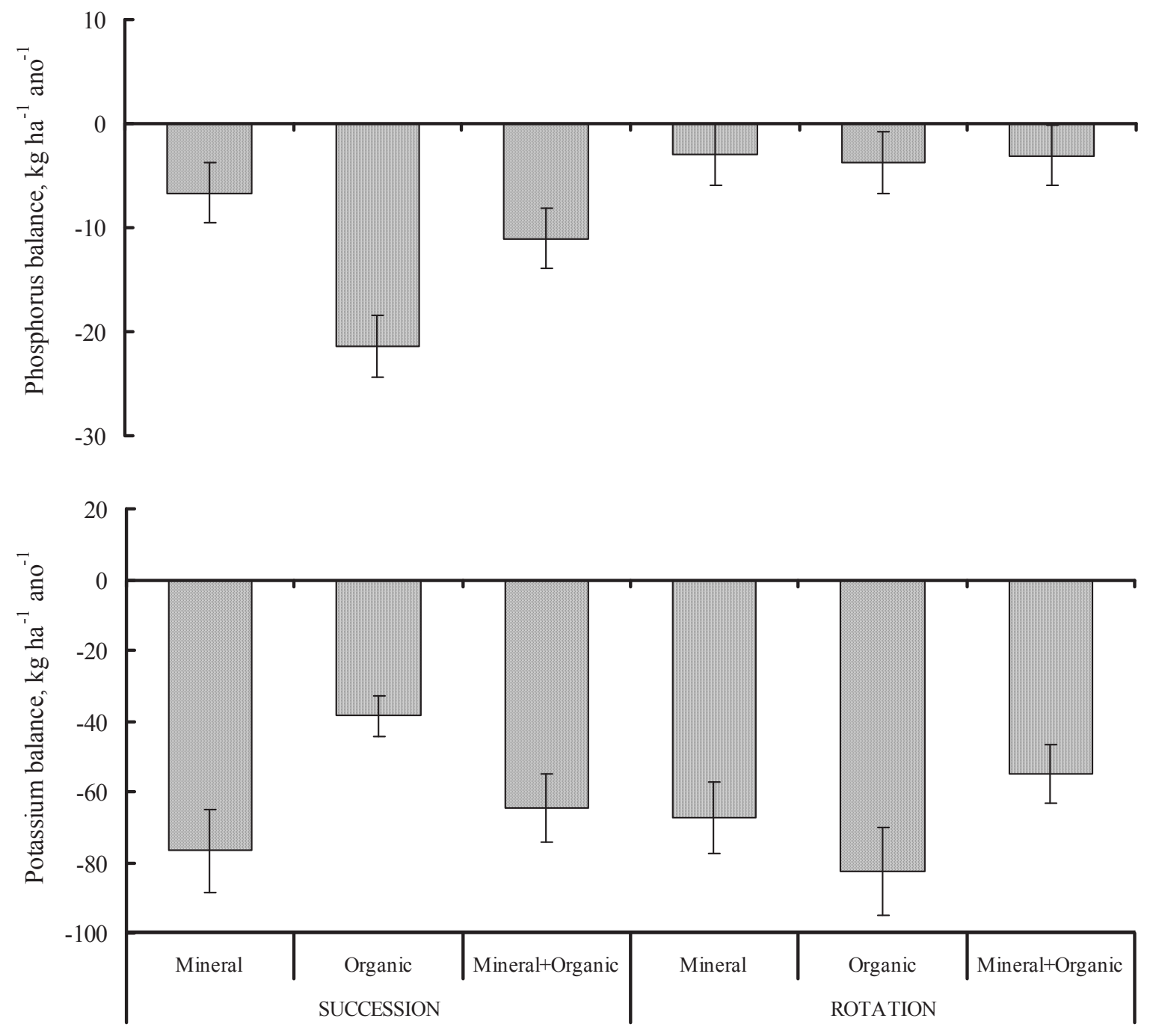

Source: Elaboration of the authors.

Soil $\mathrm{K}$ balance was determined to be negative in all treatments (Figure 4), with values ranging from -39 to $-82 \mathrm{~kg} \mathrm{ha}^{-1} \mathrm{yr}^{-1} \mathrm{~K}$ for organically-fertilized soils under the succession and crop rotation systems, respectively. In treatments undergoing mineral or mineral+organic fertilization, soil $\mathrm{K}$ balance was not affected by crop system (Figure 4). In 11 long-term experiments undertaken in five Asian countries, Dobermann, Cruz and Cassman (1996) determined that the K balance at most sites was negative, with an average net removal of 34 to
$63 \mathrm{~kg} \mathrm{ha}^{-1}$ season $^{-1}$. The same authors also observed significant depletion of soil $\mathrm{K}$ reserves at many sites.

The nature of the soil $\mathrm{K}$ balance deficit (Figure 4) indicates that it is a reflection of both $K$ in the deepest soil layers and non-exchangeable forms of the nutrient. This negative $\mathrm{K}$ balance is due in part to the increase in soil $\mathrm{K}$ levels observed during the second year of the experiment (Figure 3B) with respect to the initial amount $\left(340 \mathrm{~kg} \mathrm{ha}^{-1} \mathrm{~K}\right)$ (Table $1)$, indicating an improvement in the availability of 
this nutrient in the soil. The results presented here are similar to those reported by Rosolem, Bessa and Pereira (1993), who found that the presence of nonexchangeable tended to maintain or even enhance exchangeable $\mathrm{K}$ reserves in the soil. However, maintaining such a situation in the long term may decrease soil $\mathrm{K}$ reserves, compromising the movement of the nutrient into the soil solution and thus also the successful establishment and growth of crops.

Studies carried out in various countries across the world have found agricultural soils to be characterized by a negative $\mathrm{K}$ balance. Research investigating rice-wheat and wheat-soybean systems in India by Singh, Singh and Reddy (2002) and Bhattacharyya et al. (2006), respectively, has demonstrated that $\mathrm{K}$ application must be revised in the long term, as the currently recommended dose represents a threat to the sustainability of local agriculture by promoting the depletion of soil $\mathrm{K}$. According to both sets of authors, this deficit has been supplied by the presence of non-exchangeable forms of $\mathrm{K}$ in the soil. These findings demonstrate the importance of the forms of $\mathrm{K}$ characterizing crop nutrient supplies. In an experiment carried out in the State of Rio Grande do Sul, Brazil, Simonete et al. (2002) estimated that, even considering the residual effect of ryegrass potassium fertilization on succession-grown rice, at least $30 \%$ of the total $\mathrm{K}$ taken up by plants was in non-exchangeable form. The exploitation of $\mathrm{K}$ forms initially considered non-exchangeable for plants has been commonly reported in the literature, even in scenarios involving potassium fertilizer application (SIMONSSON; HILLIER; ÖBORN, 2009; GARCIA et al., 2008). Rosolem, Bessa and Pereira (1993) found that regardless of soil type, non-exchangeable forms of $\mathrm{K}$ were the main sources of the nutrient for soybean crops.

In production systems characterized by an absence of a fallow period between crops (plantharvest-plant system), $\mathrm{K}$ remains absorbed in plant tissue for long periods of time and is thus protected from erosion and leaching losses (FERREIRA et al., 2011). As a result, plants with a high soil K-extraction capacity and/or ability to exploit deeper soil layers are extremely important for the sustainability of agricultural production systems, both in terms of minimizing $\mathrm{K}$ losses and improving its availability in the soil.

\section{Conclusions}

In the first year of the experiment, corn yields were higher in soils applied with mineral fertilizer under the crop succession system. In the second year, however, wheat and soybean yields did not vary between the different crop systems and nutrient sources, a pattern demonstrating the residual effect of crop rotation and manure use.

The residual and cumulative effect of manure application resulted in increased soil $\mathrm{P}$ content, which could mean this nutrient became less subject to soil adsorption.

Crop rotation with cover crops resulted in an increase in soil $\mathrm{K}$ levels by promoting the recycling of this nutrient in the soil.

In both crop systems, the application of mineral and organic fertilizer - either in isolation or in combination - resulted in a negative soil $\mathrm{P}$ and $\mathrm{K}$ balance in the short term. This represents a threat to the sustainability of such an agricultural production system in the long term, due to the depletion of soil nutrient reserves.

\section{References}

ANDRIST-RANGEL, Y.; EDWARDS, A. C.; HILLIER, $\mathrm{S}$.; ÖBORN, I. Long-term $\mathrm{K}$ dynamics in organic and conventional mixed cropping systems as related to management and soil properties. Agriculture, Ecosystems and Environment, Amsterdam, v. 122, n. 4, p. 413-426, 2007.

BALIGAR, V. C.; FAGERIA, N. K.; HE, Z. L. Nutrient use efficiency in plants. Communications in Soil Science and Plant Analysis, New York, v. 32, n. 7-8, p. 921-950, 2001. 
BECK, M. A.; SANCHEZ, P. A. Soil phosphorus fraction dynamics during 18 years of cultivation on a Typic Paleudult. Soil Science Society of America Journal, Madison, v. 58, n. 5, p. 1424-1431, 1994.

BHATTACHARYYA, R.; PRAKASH, V.; KUNDU, S.; GHOSH, B. N.; SRIVASTVA, A. K.; GUPTA, H. S. Potassium balance as influenced by farmyard manure application under continuous soybean-wheat cropping system in a Typic Haplaquept. Geoderma, Amsterdam, v. 137, n. 1-2, p. 155-160, 2006.

BOER, C. A.; ASSIS, R. L.; SILVA, G. P.; BRAZ, A. J. B. P.; BARROSO, A. L. L.; CARGNELUTTI FILHO, A.; PIRES, F. R. Ciclagem de nutrientes por plantas de cobertura na entressafra em um solo de cerrado. Pesquisa Agropecuária Brasileira, Brasília, v. 42, n. 9, p. 12691276, 2007.

CALEGARI, A. Plantas de cobertura. In: CASÃO JÚNIOR, R.; SIQUEIRA, R.; MEHTA, Y. R.; PASINI, J. J. (Ed.). Sistema plantio direto com qualidade. Londrina: IAPAR; Foz do Iguaçu: ITAIPU Binacional, 2006. p. 5573.

CALEGARI, A.; CASTRO FILHO, C. de; TAVARES FILHO, J.; RALISCH, R.; GUIMARÃES, M. F. Melhoria da agregação do solo através do sistema plantio direto. Semina: Ciências Agrárias, Londrina, v. 27, n. 2, p. 147-158, 2006.

CAlONEGO, J. C.; ROSOLEM, C. A. Estabilidade de agregados do solo após manejo com rotações de culturas e escarificação. Revista Brasileira de Ciência do Solo, Viçosa, v. 32, n. 4, p. 1399-1407, 2008.

COSTA, M. S. S. M.; PIVETTA, L. A.; COSTA, L. A. M.; PIVETTA, L. G.; CASTOLDI, G.; STEINER, F. Atributos físicos do solo e produtividade do milho sob sistemas de manejo e adubações. Revista Brasileira de Engenharia Agrícola e Ambiental, Campina Grande, v. 15, n. 8, p. 810-815, 2011.

DOBERMANN, A.; CRUZ, P. C. S.; CASSMAN, K. G. Fertilizer inputs, nutrient balance, and soil nutrientsupplying power in intensive, irrigated rice systems. I. Potassium uptake and $\mathrm{K}$ balance. Nutrient Cycling in Agroecosystems, Amsterdam, v. 46, n. 1, p. 1-10, 1996.

EMPRESA BRASILEIRA DE PESQUISA AGROPECUÁRIA - EMBRAPA. Centro Nacional de Pesquisa de Solos (Rio de Janeiro, RJ). Manual de métodos de análise de solo. 2. ed. Rio de Janeiro: Embrapa Solos, 1997. 212 p.

FERREIRA, E. V. O.; ANGHINONI, I.; ANDRIGHETTI, M. H.; MARTINS, A. P.; CARVALHO, P. C. F. Ciclagem e balanço de potássio e produtividade de soja na integração lavoura-pecuária sob semeadura direta. Revista Brasileira de Ciência do Solo, Viçosa, v. 35, n. 1, p. 161-169, 2011.

GARCIA, R. A.; CRUSCIOL, C. A. C.; CALONEGO, J. C.; ROSOLEM, C. A. Potassium cycling in a cornbrachiaria cropping system. European Journal of Agronomy, Amsterdam, v. 28, n. 4, p. 579-585, 2008.

GATIBONI, L. C.; KAMINSKI, J.; RHEINHEIMER, D. S.; FLORES, J. P. C. Biodisponibilidade de formas de fósforo acumuladas em solo sob sistema plantio direto. Revista Brasileira de Ciência do Solo, Viçosa, v. 31, n. 4, p. 691-699, 2007.

GATIBONI, L. C.; RHEINHEIMER, D. S.; FLORES, A. F. C.; ANGHINONI, I.; KAMINSKI, J.; LIMA, M. A. S. Phosphorus forms and availability assessed by ${ }^{31} \mathrm{P}-\mathrm{NMR}$ in successively cropped soil. Communications in Soil Science and Plant Analysis, New York, v. 36, n. 19-20, p. 2625-2640, 2005.

GOMES, J. A.; SCAPIM, C. A.; BRACCINI, A. L.; VIDIGAL FILHO, O. S.; SAGRILO, E.; MORA, F. Adubações orgânica e mineral, produtividade do milho e características físicas e químicas de um Argissolo Vermelho Vermelho-Amarelo. Acta Scientiarum. Agronomy, Maringá, v. 27, n. 3, p. 521-529, 2005.

HANÁČKOVÁ, E.; MACÁK, M.; CANDRÁKOVÁ, E. The nutrients balance of crop rotation as an indicator of sustainable farming on arable land. Journal of Central European Agriculture, Zagreb, v. 9, n. 3, p. 431-438, 2008.

. The nutrients balance of crop rotation. Research Journal of Agricultural Science, Timisoara, v. 43, n. 1, p. 62-67, 2011.

MALAVOLTA, E.; VITTI, G. C.; OLIVEIRA, A. S. Avaliação do estado nutricional das plantas: princípios e aplicações. 2. ed. Piracicaba: Potafos, 1997. 319 p.

MARSCHNER, H. Mineral nutrition of higher plants. $2^{\text {nd }}$ ed. London: Academic Press, 1995. 889 p.

MATSI, T.; LITHOURGIDIS, A. S.; GAGIANAS, A. A. Effects of injected liquid cattle manure on growth and yield of winter wheat and soil characteristics. Agronomy Journal, Madison, v. 95, n. 3, p. 592-596, 2003.

MOSADDEGHI, M. R.; MAHBOUBI, A. A.; SAFADOUST, A. Short-term effects of tillage and manure on some soil physical properties and maize root growth in a sandy loam soil in western Iran. Soil \& Tillage Research, Amsterdam, v. 104, n. 1, p. 173-179, 2009. 
OENEMA, O.; KROS, H.; DE VRIES, W. Approaches and uncertainties in nutrient budgets: implications for nutrient management and environmental policies. European Journal of Agronomy, Amsterdam, v. 20, n. 1-2, p. 3-16, 2003.

OLIVEIRA, T. K.; CARVALHO, G. J.; MORAES, R. N. S. Plantas de cobertura e seus efeitos sobre o feijoeiro em plantio direto. Pesquisa Agropecuária Brasileira, Brasília, v. 37, n. 8, p. 1079-1087, 2002.

RAIJ, B. van; CANTARELLA, H.; QUAGGIO, J. A.; FURLANI, A. M. C. Recomendações de adubação e calagem para o Estado de São Paulo. 2. ed. Campinas: Instituto Agronômico, 1997. 285 p. (Boletim técnico, 100).

ROSOLEM, C. A.; BESSA, A. M.; PEREIRA, H. F. M. Dinâmica do potássio no solo e nutrição potássica da soja. Pesquisa Agropecuária Brasileira, Brasília, v. 28, n. 9, p. 1045-1054, 1993.

ROSOlEM, C. A.; CALONEGO, J. C.; FOLONI, J. S. S. Lixiviação de potássio da palha de coberturas de solo em função da quantidade de chuva recebida. Revista Brasileira de Ciência do Solo, Viçosa, v. 27, n. 2, p. 355362, 2003.

ROSOLEM, C. A.; SGARIBOLDI, T.; GARCIA, R. A.; CALONEGO, J. C. Potassium leaching as affected by soil texture and residual fertilization in tropical soils. Communications in Soil Science and Plant Analysis, New York, v. 41, n. 16, p. 1934-1943, 2010.
SCHERER, E. E.; NESI, C. N. Características químicas de um Latossolo sob diferentes sistemas de preparo e adubação orgânica. Bragantia, Campinas, v. 68, n. 3, p. 715-721, 2009.

SIMONETE, M. A.; VAHL, L. C.; FABRES, R. T.; COUTO, J. R. R.; LUNARDI, R. Efeito residual da adubação potássica do azevém sobre o arroz subseqüente em plantio direto. Revista Brasileira de Ciência do Solo, Viçosa, v. 26, n. 3, p. 721-727, 2002.

SIMONSSON, M.; HILLIER, S.; ÖBORN, I. Changes in clay minerals and potassium fixation capacity as a result of release and fixation of potassium in long term field experiments. Geoderma, Amsterdam, v. 151, n. 3-4, p. 109-120, 2009.

SINGH, M.; SINGH, V. P.; REDDY, D. D. Potassium balance and release kinetics under continuous rice-wheat cropping system in Vertisol. Field Crops Research, Amsterdam, v. 77, n. 2-3, p. 81-91, 2002.

SOUZA, R. F. de; FAQUIN, V.; TORRES, P. R. F.; BALIZA, D. P. Calagem e adubação orgânica: influência na adsorção de fósforo em solos. Revista Brasileira de Ciência do Solo, Viçosa, v. 30, n. 6, p. 975-983, 2006.

TAVARES FILHO, J.; BARBOSA, G. M. C.; RIBON, A. A. Physical properties of dystrophic Red Latosol (Oxisol) under different agricultural uses. Revista Brasileira de Ciência do Solo, Viçosa, v. 34, n. 3, p. 925-933, 2010.

TAVARES FILHO, J.; BARBOSA, G. M.; GUIMARÃES, M. F.; FONSECA, I. C. B. Resistência à penetração e desenvolvimento do sistema radicular do milho (Zea mays) sob diferentes sistemas de manejo em um Latossolo Roxo. Revista Brasileira de Ciência do Solo, Viçosa, v. 25, n. 3, p. 725-730, 2001. 